\title{
New Data on the Litho- and Biostratigraphy of the J/K Boundary Interval of the Lower Reaches of the Lena River (Eastern Siberia)
}

\author{
Igor N. Kosenko1,2*, Olga S. Urman'2, Egor K. Metelkin'2,3, Boris N. Shurygin ${ }^{2,3}$, \\ Alexander E. Igolnikov ${ }^{2,3}$

\footnotetext{
${ }^{1}$ State Key Laboratory of Palaeobiology and Stratigraphy, Nanjing Institute of Geology and Palaeontology CAS, Nanjing, China ${ }^{2}$ Trofimuk Institute of Petroleum Geology and Geophysics SB RAS, Novosibirsk, Russia

${ }^{3}$ Department of Geology and Geophysics, Novosibirsk State University, Novosibirsk, Russia

Email: *kosenkoin@ipg g.sbras.ru
}

How to cite this paper: Kosenko, I.N., Urman, O.S., Metelkin, E.K., Shurygin, B.N. and Igolnikov, A.E. (2019) New Data on the Litho- and Biostratigraphy of the J/K Boundary Interval of the Lower Reaches of the Lena River (Eastern Siberia). Open Journal of Geology, 9, 554-557. https://doi.org/10.4236/ojg.2019.910040

Received: August 15, 2019

Accepted: September 17, 2019

Published: September 20, 2019

Copyright $\odot 2019$ by author(s) and Scientific Research Publishing Inc. This work is licensed under the Creative Commons Attribution International License (CC BY 4.0).

http://creativecommons.org/licenses/by/4.0/

\begin{abstract}
New data on the litho- and biostratigraphy of the Jurassic/Cretaceous $(\mathrm{J} / \mathrm{K})$ boundary interval of the lower reaches of the Lena river, at the Cape Chekurovka and Cape Chucha, are presented. Volgian-Valanginian interval of the Chekurovka section is represented by Buolkalakh and Kigilyakh formations and corresponds to beds with Buchia fisheriana, beds with $B$. unschensis, beds with $B$. okensis and $B$. volgensis, beds with $B$. volgensis, beds with $B$. volgensis and $B$. tolmatschowi and beds with $B$. keyserlingi. Volgian-Valanginian interval of the Chucha section is represented by Chonoko, Khairgass and Kigilyakh formations and corresponds to beds with $B$. unschensis, beds with $B$. volgensis and $B$. okensis, beds with $B$. volgensis and B. tolmatschowi and beds with $B$. keyserlingi.
\end{abstract}

\section{Keywords}

Stratigraphy, Jurassic, Cretaceous, Siberia, Lena River

In the summer 2018 expedition group of IPGG SB RAS has studied the J/K boundary interval in the sections of Chekurovka and Chucha located in the lower reaches of the Lena river (Figure 1). As a result, bio- and lithostratigraphy have been clarified.

On the Cape Chekurovka Volgian-Valanginian deposits with stratigraphic unconformity overlie condensated Oxfordian sandstones (Figure 1). Volgian-Ryazanian part of the section belongs to the Buolkalakh Formation and consists of alternated greenish-grey and grey siltstones and light-grey sandstones 


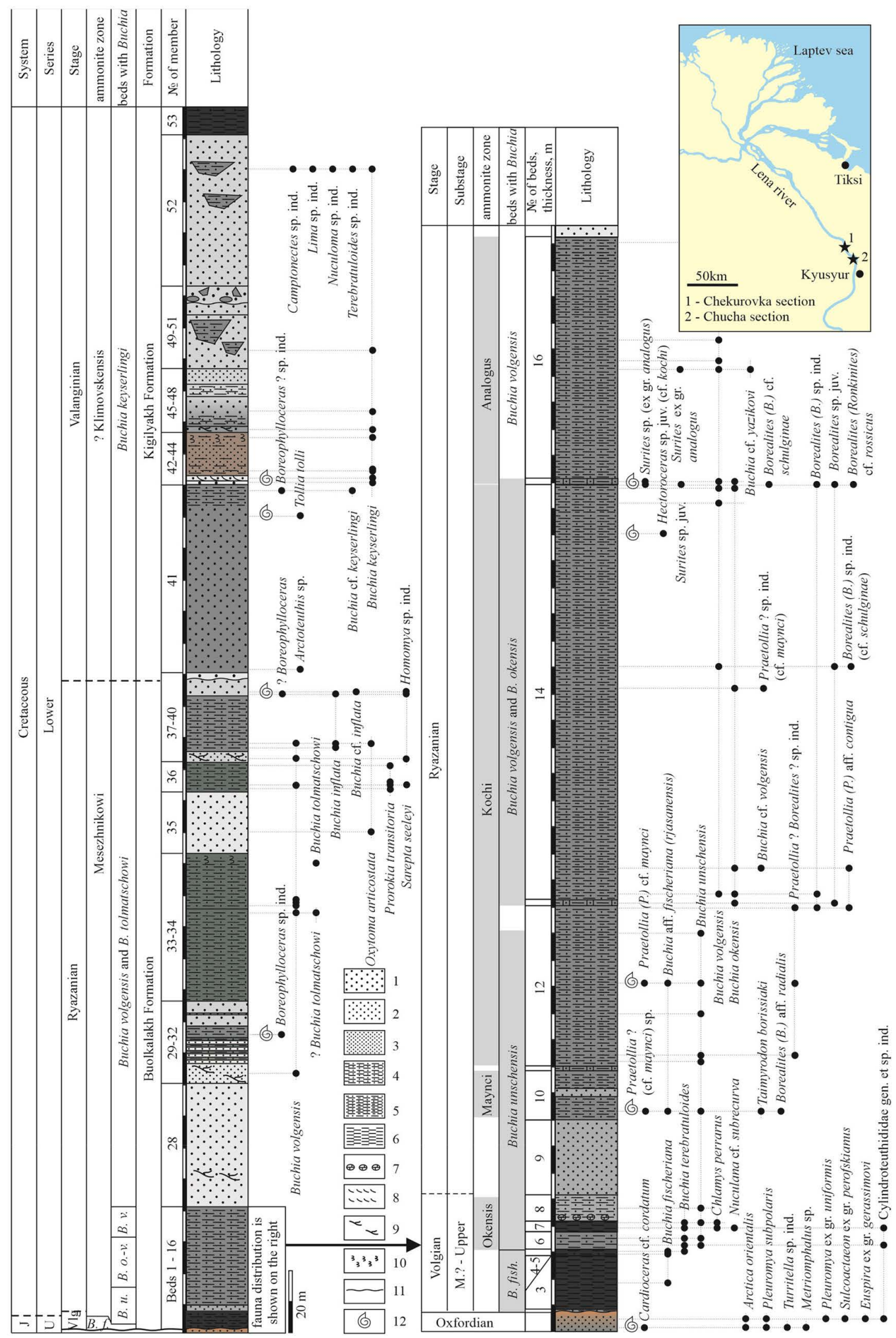

Figure 1. Litho- and biostratigraphy of the Chekurovka section and map with locations of the Chekurovka and the Chucha sections. Numeration of beds and members is given after [1]. Legend: 1: coarse sandstone, 2: medium-grained sandstone, 3: fine-grained sandstone, 4: siltstone, 5: clayey siltstone, 6: silty argillite and argillite, 7: carbonate nodules, 8: oblique lamination, 9: carbonized plant detritus, 10: bioturbation, 11: erosional surface, 12: finding of ammonites. 
with black and dark-grey argillites and siltstones in the lower part. The total thickness of the formation is more than $220 \mathrm{~m}$. The Valanginian Kigilyakh Formation which overlies the Buolkalakh Formation consists of sandstones with breccias and silty argillites in the upper part. The boundary between Buolkalakh and Kigilyakh formations is marked by an erosional surface. The total thickness of the Kigilyakh Formation is more than $180 \mathrm{~m}$.

Succession of Buchia, typical for the Boreal Scale, has been identified in the Chekurovka section: beds with $B$. fisheriana, beds with $B$. unschensis, beds with $B$. okensis and $B$. volgensis, beds with $B$. volgensis, beds with $B$. volgensis and $B$. tolmatschowi, and beds with $B$. keyserlingi (Figure 1). Beds with $B$. fisheriana comprise also B. terebratuloides in the upper part. Based on ammonite Praechetaites sp. nov. this interval previously has been correlated with uppermost Middle Volgian [1]. Beds with $B$. unschensis comprise $B$. terebratuloides in the lower part. Beds with $B$. okensis contain single $B$. cf. yazikovi. Beds with $B$. volgensis and $B$. tolmatschowi also contain $B$. inflata in the upper part. The Ryazanian/Valanginian boundary is conventionally marked on the erosional surface between members 39 and 40 [1]. The Valanginian part of the section corresponds to beds with $B$. keyserlingi.

Section on the Cape Chucha is located approximately $20 \mathrm{~km}$ south of the Chekurovka section. It differs from the Chekurovka section by its lithostratigraphic construction. This is linked with its position near the boundary of Olenek and Lower Lena facial regions where sedimentation occurred in shallower part of sea compared to Chekurovka [2]. Volgian part of the Chucha section with stratigraphic unconformity overlies Oxfordian sediments and consists of sandstones and siltstones of the Chonoko Formation. The Ryazanian Khairgass Formation mainly consists of whitish-grey sandstones alternated with greenish-grey and grey siltstones. It is conformable overlaid by the Kigilyakh Formation represented here by rhythmic alternating of fine-grained sandstones and siltstones with beds of sandstones and silty argillites. The total thickness of Volgian-Valanginian deposits is more than $300 \mathrm{~m}$. The following succession of beds with Buchia is identified in the Chucha section: beds with $B$. unschensis, beds with $B$. volgensis and B. okensis, beds with $B$. volgensis and B. tolmatschowi, and beds with $B$. keyserlingi.

\section{Acknowledgements}

This work is supported by the Chinese Academy of Geological Sciences (DD20190009), National Natural Science Foundation of China (41730317), RFBR (18-05-70074) and RSF (18-17-00038). This is a contribution to UNESCO-IUGS IGCP Projects 632 and 679.

\section{Conflicts of Interest}

The authors declare no conflicts of interest regarding the publication of this paper. 


\section{References}

[1] Rogov, M.A., Zakharov, V.A. and Ershova, V.B. (2011) Detailed Stratigraphy of the Jurassic-Cretaceous Boundary Beds of the Lena River Lower Reached Based on Ammonites and Buchiids. Stratigraphy and Geological Correlation, 19, 641-662. https://doi.org/10.1134/S0869593811060050

[2] Bidzhiev, R.A. (1973) Volzhskii yarus na severe Priverkhoyanskogo progiba (vnutrennyaya zona). Byull. Mosk. O-va Ispyt. Prir., Otd. Geol., 48, 61-71. 